\title{
Calibration and Validation of the EPIC Model for Maize Production in the Eastern Cape, South Africa
}

\author{
Dennis Junior Choruma ${ }^{1, * \mathbb{D}}$, Juraj Balkovic ${ }^{2,3}$ and Oghenekaro Nelson Odume ${ }^{1, *}$ \\ 1 Institute for Water Research, Rhodes University, Grahamstown 6139, South Africa \\ 2 International Institute for Applied Systems Analysis, 2361 Laxenburg, Austria \\ 3 Faculty of Natural Sciences, Comenius University in Bratislava, 84215 Bratislava, Slovak \\ * Correspondence: denychor@gmail.com (D.J.C.); nelskaro@yahoo.com (O.N.O.); Tel.: +27-(0)46-6037701
}

Received: 12 July 2019; Accepted: 11 August 2019; Published: 29 August 2019

\begin{abstract}
Crop models are useful tools to evaluate the effects of agricultural management on ecosystem services. However, before they can be applied with confidence, it is important to calibrate and validate crop models in the region of interest. In this study, the Environmental Policy Integrated Climate (EPIC) model was evaluated for its potential to simulate maize yield using limited data from field trials on two maize cultivars. Two independent fields at the Cradock Research Farm were used, one for calibration and one for validation. Before calibration, mean simulated yield was $8 \mathrm{tha}^{-1}$ while mean observed yield was $11.26 \mathrm{t} \mathrm{ha}^{-1}$. Model calibration improved mean simulated yield to $11.23 \mathrm{t} \mathrm{ha}^{-1}$ with a coefficient of determination, $\left(r^{2}\right)=0.76$ and a model efficiency (NSE) $=0.56$. Validation with grain yield was satisfactory with $r^{2}=0.85$ and NSE $=0.61$. Calibration of potential heat units (PHUs) and soil-carbon related parameters improved model simulations. Although the study only used grain yield to calibrate and evaluate the model, results show that the calibrated model can provide reasonably accurate simulations. It can be concluded that limited data sets from field trials on maize can be used to calibrate the EPIC model when comprehensive experimental data are not available.
\end{abstract}

Keywords: irrigation; fertilizer; management; crop model; decision support; field experiment

\section{Introduction}

With the world population projected to reach over 9 billion people by the year 2050, agriculture is expected to meet the rising demand for food and fiber from limited land and water resources $[1,2]$. However, increases in agricultural production should not come at the expense of land and water resources as they are critical resources needed for food production. A key area of interest in agronomic research, therefore, is to find agricultural land management strategies that maximize food production without degrading land and water resources (also known as sustainable intensification). In order to develop such strategies, field experiments have been used to investigate the impacts of different management strategies on crop yields and the environment [3-5]. Field experiments are sources of reliable data for establishing causal relationships between agricultural land management practices and real-world observed measurements [6,7]. However, field experiments are often expensive, time-consuming, and labor-intensive.

Crop growth simulation models are alternative methods that offer a quicker and less expensive way of investigating the effects of agricultural land management practices on crop yields and the environment. A modelling approach can provide reasonably reliable results in developing agricultural land management strategies, provided the models are calibrated and validated using reliable observed field data [8,9]. For example, crop models have been applied to refine management practices, such as fertilizer application and water usage at the farm and plot scales [10]. Further, crop models have been 
used to test the effectiveness of alternative agricultural land management practices under varying climate change scenarios. However, to yield meaningful results, it is prudent to calibrate crop models in the region of intended use before their application [11].

Model calibration is the procedure where model parameters are fine-tuned to increase the agreement between model simulations and real-world observations [12]. Calibration is important to increase model accurateness and decrease model prediction uncertainty [13]. Calibration is done by judiciously choosing model parameter values, adjusting them within recommended ranges, for example, from literature or expert opinions, and comparing the simulated outputs with observed data for a given set of conditions [14]. A successful calibration would be when the model reproduces observed data within a satisfactory degree of accuracy and precision for the intended model use $[15,16]$. Once calibrated and validated, the model can be reasonably applied in the area of interest. Calibrated crop growth models can, therefore, be useful tools to complement field experiments and support decision making for sustainable agricultural land management.

The Environmental Policy Integrated Climate (EPIC) model [17], originally developed in the United States of America (USA), is a process-based, field-scale model with a daily time scale. It simulates the chemical processes occurring in the soil-water-plant interaction under different agricultural management regimes [18]. The main components of EPIC are weather simulation, crop growth, carbon and nutrient cycling, tillage, soil erosion, and hydrology [19]. Globally, the model has been applied to study crop yield responses to nutrients and water management [20,21], irrigation management and scheduling [22,23], soil erosion [24], and climate change impacts on crop yields [25,26]. However, the majority of these studies have been conducted at the global and regional scales using a Geographic Information Systems (GIS) modified version of the EPIC model, Global-EPIC (GEPIC), with few studies conducted in South Africa.

In Africa, studies using EPIC have mostly been performed in West Africa [27-29] where soil and weather conditions differ from the semi-arid conditions in South Africa. Studies that have applied EPIC in South Africa have been at the sub-Saharan scale [11,30] where combined data from provincial statistics have been used to calibrate models due to data scarcity issues [31,32]. The application of the EPIC model at the regional scale in Africa implies that field-scale conditions, such as local heterogeneity in climate, soil, and farm management practices, are difficult to incorporate, potentially resulting in high levels of uncertainties in model results [33,34]. The use of field-scale data can greatly increase model accuracy and reduce uncertainty in model predictions, particularly if results are to guide local decision-making processes.

To date, information on field-scale calibration and validation studies using EPIC in South Africa are limited. In South Africa, the models that have been applied widely in the field of agricultural management have been the Agricultural Catchments Research Unit (ACRU) model [35,36], Decision Support System for Agrotechnology Transfer (DSSAT) [37] and the Soil Water Balance (SWB) model [38]. However, the majority of these models have mostly been hydrological models that have been adapted for agricultural water management and lack a robust crop growth and fertilizer management component compared to EPIC, which was specifically developed for agricultural management [17]. Therefore, using limited field data (maize grain yield only) from the Cradock Research Farm in the Eastern Cape, the objectives of this study were to: (a) calibrate the EPIC model for maize yield simulation using field-scale data under South African conditions and (b) validate the EPIC model for maize yield simulation using independent maize yield data from another site. A global EPIC-based modelling framework (EPIC-IIASA) was used to generate field-scale data needed to carry out the simulations.

\section{Materials and Methods}

\subsection{Study Site}

Field studies for calibration of the EPIC model were carried out at the Cradock Research Farm in the Eastern Cape, South Africa ( $32^{\circ} 13^{\prime} 11.09^{\prime \prime}$ S, $25^{\circ} 41^{\prime} 11.86^{\prime \prime}$ E, elevation $\left.849 \mathrm{~m}\right)$. The Cradock Research 
Farm is situated within the Great Fish River valley catchment (Figure 1), where intensive irrigation and commercial farming are practiced. Soils and climate within the research farm are representative of the broader catchment. The soil is classified as a fine-loamy mollic ustifluvent [39] of alluvial origin, characterized by high sand and silt contents of the alluvial and colluvial material derived from Beaufort sediments in the Eastern Cape. Table 1 shows the general characteristics of the soil profile used in the study. Cradock has an average annual rainfall of $341 \mathrm{~mm}$ with the majority of the rainfall occurring in February and March (late summer). Cradock is mostly a farming town, situated along the Great Fish River where water from the river is used for irrigation purposes. Declining soil productivity and increasing water scarcity due to low rainfall and frequent droughts have led to an increase in the use of irrigation water and fertilizer inputs on most farms to maintain agricultural productivity. Consequently, the increased use of fertilizer and irrigation water has led to a deterioration of environmental water quality in commercial farming areas [40].

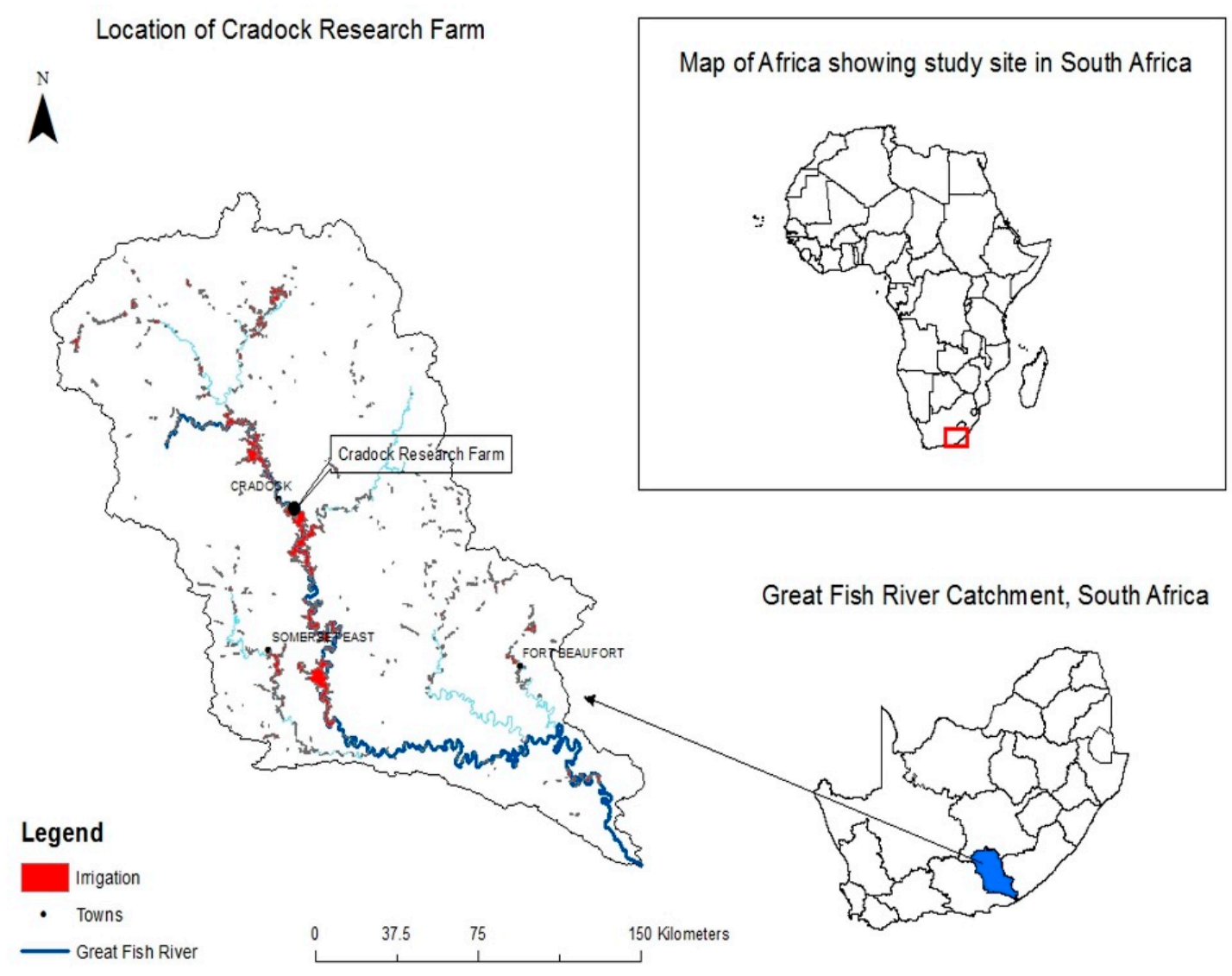

Figure 1. Map of Africa showing South Africa and the location of the Cradock Research Farm within the Great Fish River System.

Table 1. Selected soil properties and depths of the soil profile used as input into the Environmental Policy Integrated Climate (EPIC) model at Cradock Research Farm.

\begin{tabular}{ccc}
\hline Soil Parameters & \multicolumn{2}{c}{ Soil Layer Number } \\
& $\mathbf{1}$ & $\mathbf{2}$ \\
\hline Bulk density $\left(\mathrm{g} \mathrm{cm}^{-3}\right)$ & 1.48 & 1.52 \\
Clay $(\%)$ & 20.4 & 15.1 \\
Sand (\%) & 52.8 & 42.5 \\
Silt (\%) & 26.8 & 42.4 \\
pH (water) & 6.5 & 6.5 \\
Soil organic carbon $(\%)$ & 0.91 & 0.2 \\
Cation exchange capacity $\left(\mathrm{cmol}(+) \mathrm{kg}^{-1}\right)$ & 14.3 & 13.4 \\
\hline
\end{tabular}




\subsection{Field Experiment}

Field trials on maize were carried out at Cradock Research Farm for the Agricultural Research Council (ARC) by the Cradock research manager from 1999 to 2003. The field trials were carried out to evaluate the potential yield and cultivar stability of different high-yielding maize hybrid cultivars under the semi-arid conditions of the Eastern Cape. Two maize hybrid cultivars, CRN 3760 and $\mathrm{PHB} 30 \mathrm{H} 22$, were chosen for the modelling study as they had complete records for grain yield and agricultural management for the period 1999 to 2003. The maize varieties selected for the modelling study were grown on two independent fields with similar soils at the Cradock Research Farm but managed according to the same irrigation and fertilizer regime. A randomized block design (RBD) [41], with three replications, was used throughout. Plant population was at 50,000 plants per hectare with a row spacing of $0.9 \mathrm{~m}$.

A standard management plan developed by ARC was used to schedule agricultural management practices, including irrigation amount and timing, fertilizer amount, and planting densities. Irrigation type was flood irrigation with the crop receiving a maximum of $600 \mathrm{~mm}$ irrigation water per growing season. Nitrogen fertilizer was applied at a rate of $195 \mathrm{~kg} \mathrm{~N} \mathrm{ha}^{-1}$ season ${ }^{-1}$. Soil tillage was done using a power plow, and common weed and pest control were carried out as needed. Table 2 shows the typical irrigation and fertilizer amounts used during the trial period. This agricultural management plan was used throughout the trial period from 1999 to 2003. During the trial period, the same management practices were performed around the same time each year with only minor changes according to prevailing local weather conditions.

Table 2. Summary of management plan used for both field sites during the five years of the trial period.

\begin{tabular}{|c|c|c|c|}
\hline Date $^{1}$ & Operation & Type & Amount \\
\hline 22 October & Planting & Maize & 50,000 plants ha ${ }^{-1}$ \\
\hline 22 October & Fertilizer application & Superphosphate & $476 \mathrm{~kg} \mathrm{ha}^{-1}$ \\
\hline 22 October & Fertilizer application & Ammonium sulfate & $330 \mathrm{~kg} \mathrm{ha}^{-1}$ \\
\hline 22 October & Fertilizer application & Calcium sulfate & $120 \mathrm{~kg} \mathrm{ha}^{-1}$ \\
\hline 22 October & Irrigation & Furrow & $75 \mathrm{~mm}$ \\
\hline 15 November & Fertilizer application & Ammonium sulfate & $300 \mathrm{~kg} \mathrm{ha}^{-1}$ \\
\hline 26 November & Irrigation & Furrow & $75 \mathrm{~mm}$ \\
\hline 10 December & Fertilizer application & Ammonium sulfate & $300 \mathrm{~kg} \mathrm{ha}^{-1}$ \\
\hline 17 December & Irrigation & Furrow & $75 \mathrm{~mm}$ \\
\hline 28 December & Irrigation & Furrow & $75 \mathrm{~mm}$ \\
\hline 18 January & Irrigation & Furrow & $75 \mathrm{~mm}$ \\
\hline 8 February & Irrigation & Furrow & $75 \mathrm{~mm}$ \\
\hline 19 February & Irrigation & Furrow & $75 \mathrm{~mm}$ \\
\hline 11 March & Irrigation & Furrow & $75 \mathrm{~mm}$ \\
\hline 5 June & Harvesting & Manual & 11 tonnes hectare $^{-1}$ (average) \\
\hline
\end{tabular}

\footnotetext{
1 The dates given in the table are not fixed for each year. They indicate the approximate times of year each
} management activity was carried out during the trial period.

It should be noted that although agricultural management practices were recorded during the trial period, most variables that would be useful in evaluating model performance, such as soil organic carbon contents, leaf area index, and nitrogen content in grain, were not recorded during the trial period. Only the final grain yield was recorded, and this limited the observed data that could be compared with model outputs.

\subsection{Model Description}

The EPIC model simulates approximately 80 crops with the model using unique parameter values for each crop [18]. In the crop growth routine, crop yield is estimated as a function of the potential and water-limited harvest index (HI, WSYF), biomass to energy ratio (WA), planting density (PD), photosynthetic active radiation (PAR), and vapor pressure deficit (VPD) [26]. Potential biomass is 
adjusted to actual biomass through daily stress caused by extreme temperature, water, and nutrient stress or inappropriate aeration. Values of context-specific parameters such as potential heat units accumulated by a crop from its sowing to maturity (PHU), harvest index (HI) and optimum temperature (OT) need to be adjusted according to the region and context in which the model is to be applied.

\subsection{Data Sources}

Daily weather data for the Eastern Cape, which included precipitation, maximum and minimum temperature, solar radiation, and relative humidity for the years 1980-2010 were obtained from the publicly available AgMERRA [42] climate dataset at $0.5 \times 0.5$ arc-degree spatial resolution. Soil data (bulk density, cation exchange capacity, texture, and electrical conductivity) were obtained from records of previous soil analyses done at the Cradock Research Farm. However, some soil parameters required to set up the EPIC model were missing, and these were obtained from the Harmonized World Soil Database (HSWD) [43]. The missing soil parameters in the EPIC soil file were then adjusted with values from the HSWD based on expert opinion [44]. Agricultural management data, such as fertilizer application, irrigation amount, and planting and harvesting dates during the trial period, were obtained from the Cradock Research Farm manager [44].

Initial PHUs were estimated from long term (1980-2010) daily maximum and minimum temperature values and optimal temperature for maize growth using the PHU calculator at Purdue University, Indiana, USA. Base (minimum temperature for plant growth) and OT were set to $8{ }^{\circ} \mathrm{C}$ and $25^{\circ} \mathrm{C}$, respectively, according to values in the ARC Maize production guideline [45]. The number of days from planting to maturity were obtained from the maize hybrid variety producer [46]. Planting and harvesting dates recorded during the trial period were also used as inputs. Together, the long-term maximum and minimum temperature data, base and optimum temperature, as well as the number of days from planting to maturity were used to estimate the potential heat units required from planting to maturity based on the following heat unit formulas:

$$
\begin{gathered}
\text { Daily Heat Unit }=\frac{\text { maximum temperature }+ \text { minimun temperature }}{2} \\
\text {-threshold Temperature } \\
\text { PHU = Daily Heat Units } \times \text { Number of days from planting to harvest }
\end{gathered}
$$

Based on this calculation, initial potential heat units were set to 2340 and the duration of the growing season set to 180 days.

Annual grain yield and management practices including tillage, fertilization, sowing, planting, irrigation, and harvesting dates were recorded on site. Data for the period 1999-2003 from one field site were used to calibrate the model while data from the second field site were used for model validation. The agricultural management plan provided by the Cradock Farm manager was used as input for fertilizer application timing, irrigation scheduling, and planting and harvesting times. Based on the management plan, the corresponding crop operation schedules, including tillage, fertilizer application, irrigation timing, planting, and harvesting dates were designed in EPIC's Operations Schedule file for each site.

\subsection{Model Setup}

The EPIC-IIASA modelling framework [47] was used in this study. Obtained data sets were converted to simulation grids at a resolution of $5 \times 5$ arc-min. The modelling scheme was set up by combining available GIS layers on soil, relief, and weather $[12,19]$. The model was constructed for the whole of the Eastern Cape and divided into homogenous response units according to physical properties given by the intersection of site properties, such as elevation and soil texture. Subsequently, a zone raster was defined, consisting of homogenous simulation units and weather grids upon which the model was run [47]. For this study, the simulation grid in which Cradock was located was chosen for model simulations. One soil profile adjusted for soil properties experienced in the study area (see 
Section 2.1) was therefore used to run the simulations in the model. The Priestly-Taylor method for potential evapotranspiration (PET) was used in the model for estimation of PET. The Priestly-Taylor method was chosen because it gave PET values close to previously reported values for PET in the region compared to other methods of estimating PET [48].

The model was run for 31 years from 1980 to 2010, corresponding to the length of the weather records. Simulated crop yields were compared to observed yields from the period 1999 to 2003 with the initial 19 years serving as a warm-up period for equilibrating soil functions, water erosion, as well as soil nutrient depletion. Irrigation and fertilizer application were set to manual scheduling and input into the operations schedule file based on dates recorded during the field trials (Table 2).

\subsection{Model Calibration and Validation}

\subsubsection{Parameters Identification}

During calibration, few adjustments were made to the default parameters to reflect local crop cultivars and site conditions. Earlier studies in semi-arid conditions by [49], [50], and [20] have found simulated crop yields to be sensitive to: (i) potential heat units (PHU, Equation (2)); (ii) planting density (PD), the number of plants per unit area; (iii) biomass to energy ratio (WA), defined as the potential growth per unit of intercepted photosynthetically active radiation; (iv) harvest index (HI) or ratio of economic yield to above-ground biomass; and (v) microbial decay rate. These parameters were selected for calibration to adjust simulated yields to correspond to observed yields as closely as possible. The choice of parameters to calibrate was based mainly on observed available data and also on suggestions from EPIC developers following [51].

\subsubsection{Calibration Procedure}

Calibration was done according to the steps in Figure 2 adapted from [12].

Simulation 0: Simulation with Default Parameters

The default maize crop parameter dataset (provided with EPIC version 0810) was used as the starting basis to establish a modified parameter set for maize yield simulation. The default maize parameters were modified using data from the calibration period (1999-2003) and values from literature to account for the local context. The modified parameter set was then used to run a simulation for the period 1980 to 2010. HI and WA were set to their default values of 0.5 and $40 \mathrm{~kg} \mathrm{ha}^{-1} \mathrm{MJ}^{-1} \mathrm{~m}^{2}$, respectively. PHUs were set to 2340 according to calculations using the growing season length and the maximum and minimum temperatures. Irrigation and fertilizer application were both set to manual and input into the operations schedule file according to the management records obtained from the Cradock Station manager. Planting and harvesting dates were also taken from management records. Planting density was set to 5 plants per square meter based on management records.

Simulation 1: Parameter Adjustment

Model parameters influencing soil organic carbon and crop growth were adjusted based on literature, site history [44], and expert knowledge [52]. The value that gave the lowest root-mean-square error (RMSE, Equation (3)) between observed yields and simulated yields was selected as the final calibration value. Table 3 shows the parameters adjusted and the values before and after calibration. The microbial decay rate coefficient Parm (20) was set to 1 after values reported in previous EPIC modelling frameworks, such as EPIC-BOKU [53]. The microbial decay rate coefficient impacts carbon mineralization, which affects crop yield [49]. Century slow humus transformation rate (Parm 47) and exponential coefficient in equation expressing tillage effect on residue decay rate (Parm 52) affect carbon dynamics and must be estimated to simulate nitrogen supply correctly. The minimum HI under water stress (WSFY) was set to 0.01 from 0.4 , which gives a stronger weight to water stress in the model's calculation of HI [11]. 


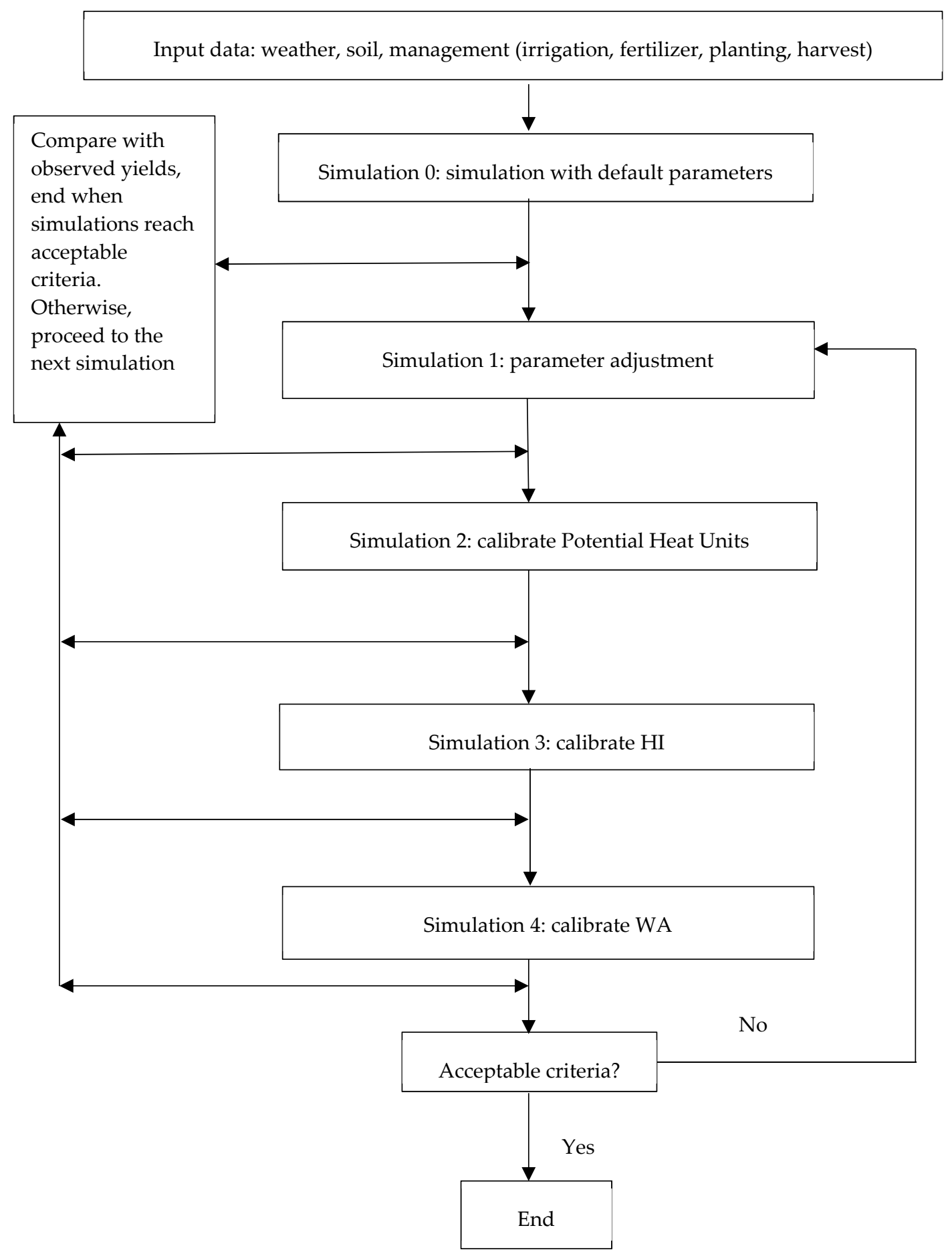

Figure 2. Steps followed in the calibration process (adapted from [12]). 
Table 3. Crop and carbon cycle-related parameters, default values, suggested parameter ranges, and calibrated values in the EPIC model.

\begin{tabular}{cccccc}
\hline Parameter & Symbol & $\begin{array}{c}\text { Default } \\
\text { Value }\end{array}$ & $\begin{array}{c}\text { Calibrated } \\
\text { Value }\end{array}$ & $\begin{array}{c}\text { Suggested } \\
\text { Range }\end{array}$ & Source \\
\hline Crop parameters & & & & & \\
Potential heat units & PHU & 2340 & 2480 & $1000-2900$ & {$[54]$} \\
Minimum harvest index & WSFY & 0.40 & 0.01 & $0.01-0.40$ & {$[18]$} \\
$\quad$ Harvest index & HI & 0.5 & 0.5 & $0.45-0.60$ & {$[55]$} \\
Biomass to energy ratio & WA & 40 & 40 & $30-45$ & {$[56]$} \\
$\begin{array}{c}\text { Carbon cycle parameters } \\
\text { Microbial decay rate coefficient }\end{array}$ & Parm (20) & 0.1 & 1.00 & $0.5-1.5$ & {$[49]$} \\
$\begin{array}{c}\text { Slow humus transformation rate } \\
\text { Tillage effect on Residue decay rate }\end{array}$ & Parm (47) & 0.000548 & 0.00068 & $0.00041-0.00068$ & {$[57]$} \\
Exponential coefficient in potential & Parm (52) & 5 & 6.20 & $5-15$ & {$[58]$} \\
water use root growth distribution & Parm (54) & 5 & 2.5 & $2.5-7.5$ & {$[18]$} \\
\hline
\end{tabular}

Simulation 2: PHU Adjustment

PHUs were adjusted in steps of 5 to match observed yields as closely as possible. The PHUs that gave the lowest RMSE between observed and simulated yields were selected as the final calibrated PHU.

Simulation 3: HI Adjustment

$\mathrm{HI}$ has been shown to vary across locations and management practices [59]. In the $\mathrm{HI}$ adjustment simulation, $\mathrm{HI}$ was adjusted from 0.4 to 0.8 in steps of 0.05 to explore the effects of varying $\mathrm{HI}$ on crop yields.

\section{Simulation 4: WA Adjustment}

WA is used in the model for converting energy to biomass. Different values of WA were changed by steps of 5 to explore the influence of WA on crop growth. WA has been shown to significantly affect crop yield and should be one of the last parameters to be adjusted [18].

\subsection{Statistical Analyses}

To evaluate model efficiency in predicting observed yields, the following statistics were computed: Root-mean-square error (RMSE), the coefficient of determination $\left(R^{2}\right)$, Nash-Sutcliffe efficiency (NSE) and percent bias (PBIAS).

$$
\begin{gathered}
\text { RMSE }=\left[\frac{1}{n} \sum_{i=1}^{n}\left(s_{i}-o_{i}\right)^{2}\right]^{\frac{1}{2}} \\
R^{2}=\frac{\left[\sum\left(O_{i}-O_{\text {mean }}\right)\left(S_{i}-S_{\text {mean }}\right)\right]^{2}}{\sum\left(O_{i}-O_{\text {mean }}\right)^{2} \sum\left(S_{i}-S_{\text {mean }}\right)^{2}} \\
\text { NSE }=1-\frac{\sum_{i=1}^{n}\left(O_{i}-S_{i}\right)^{2}}{\sum_{i=1}^{n}\left(O_{i}-O_{\text {mean }}\right)} \\
\text { PBIAS }=\frac{\sum_{i=1}^{n} 100\left(O_{i}-S_{i}\right)}{\sum_{i=1}^{n} O_{i}}
\end{gathered}
$$

where $n$ is the sample number, $O_{\text {mean }}$ and $S_{\text {mean }}$ are the observed mean and simulated mean values, respectively. $\mathrm{O} i$ and $S i$ are the observed and predicted values of the $i$ th observation ( $i=1$ to $n$ ), respectively. For RMSE, values closer to zero imply a good fit between observed and simulated yields [60]. A value of zero for RMSE means that the model predicts the observations with perfect accuracy. The coefficient of determination, $\mathrm{R}^{2}$, ranges from 0 to 1 , with higher values indicating less error variance [16]. NSE ranges from negative infinity to 1. A value of NSE equal to 1 represents 
a perfect model fit, and negative NSE values indicate that the mean observed value is a better predictor than the simulated value [16]. PBIAS measures the tendency of simulated data to be larger or smaller than the observed data. It has an optimal value of 0 , with positive values indicating underestimation and negative values indicating overestimation [61]. Differences in mean values between observed and simulated values were evaluated using the Student's $t$-test in Excel 2016. Model performance was considered satisfactory if $r^{2} \geq 0.6$, PBIAS $\leq \pm 25 \%$ and NSE $\geq 0.4$ following [62].

\section{Results}

\subsection{Model Calibration}

\subsubsection{Simulation with Default Parameters}

The simulation with default parameters showed an overall underestimation of observed yields with PBIAS $=17.6, r^{2}=0.02$, RMSE $=3.65 \mathrm{tha}^{-1}$, and NSE $=-3.3$. Simulated yields ranged from 7 tonnes per hectare ( $\mathrm{t} \mathrm{ha}{ }^{-1}$ ) to $8.3 \mathrm{t} \mathrm{ha}^{-1}$ while observed yields ranged from $9 \mathrm{tha}^{-1}$ to $14 \mathrm{t} \mathrm{ha}^{-1}$. The model underestimated crop yields for all years, as shown in Figure 3.

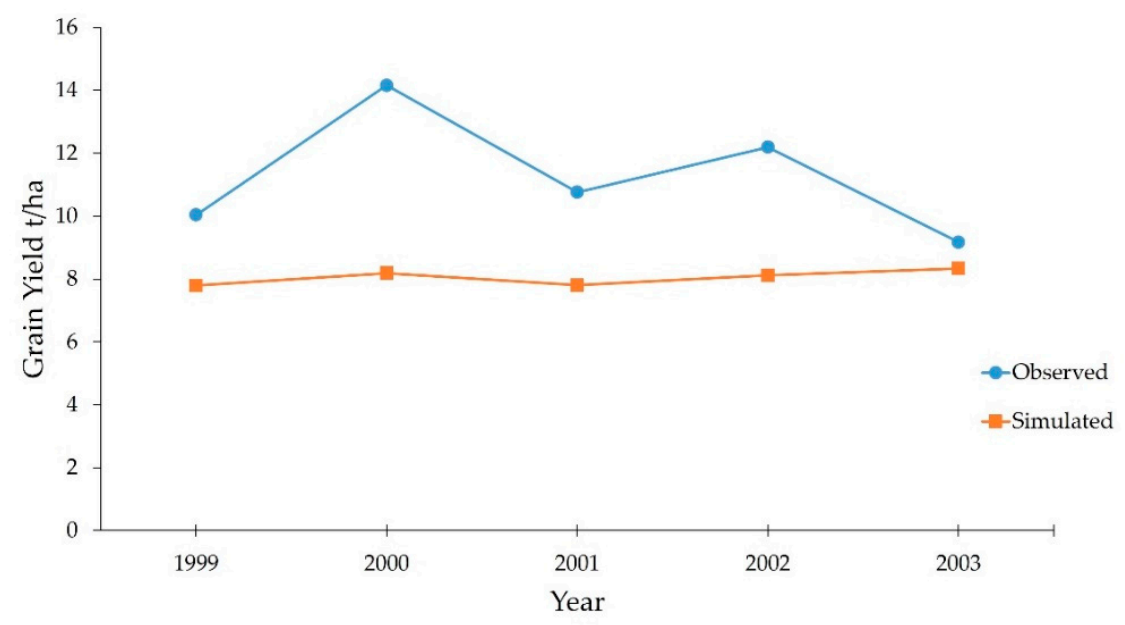

Figure 3. Simulation with default parameters showing the simulated yields for the weather period with observed data.

\subsubsection{Parameter Adjustment}

Adjusting the parameters Parm 20, Parm 47, Parm 52, Parm 54 and WSFY improved RMSE from $3.65 \mathrm{tha}^{-1}$ in the default simulation to $1.28 \mathrm{t} \mathrm{ha}^{-1}$. Model efficiency, as expressed by NSE improved from negative values to 0.47 . Further parameters adjustment did not improve model simulations. The calibrated parameter values are summarized in Table 3.

\subsubsection{PHU Calibration}

The initial PHU calculated from long-term weather records gave a RMSE of $1.86 \mathrm{t} \mathrm{ha}^{-1}$ between the observed and simulated yields. Increasing PHU value improved model simulations with the PHU value of 2480 giving the lowest RMSE value of $1.17 \mathrm{tha}^{-1}$. Further adjustments of PHU above 2480 did not yield any improvement of RMSE. Following up on the parameter adjustment in the previous section, calibrating PHU brought model simulations within the criteria set for satisfactory model calibration $\left(r^{2}>0.6\right.$ and PBIAS $\left.< \pm 25 \%\right)$ and further calibration of the crop parameters HI and WA was not performed. In this calibration simulation with $\mathrm{PHU}=2480$, simulated crop yields ranged from $10 \mathrm{t} \mathrm{ha}^{-1}$ to $12 \mathrm{t} \mathrm{ha}^{-1}$ while observed yields ranged from $9 \mathrm{t} \mathrm{ha}^{-1}$ to $14 \mathrm{t} \mathrm{ha}^{-1}$ (Figure 4). 


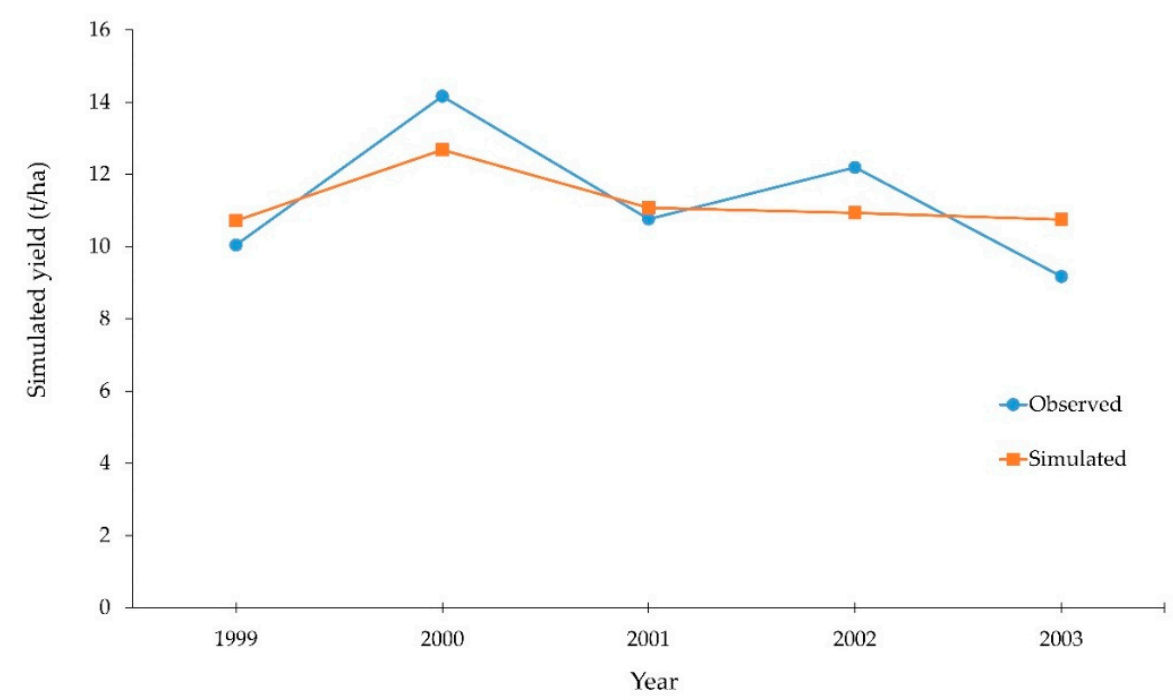

Figure 4. Comparison of observed yields in tonnes per hectare $\left(\mathrm{t} \mathrm{ha}^{-1}\right)$ and simulated yields for the period with observed data after initial potential heat units (PHUs) calibration of the model.

Final PHU calibration results showed a coefficient of determination $\left(r^{2}\right)$ between simulated and observed yields of 0.76 (Figure 5). A Nash-Sutcliffe efficiency of 0.56 and a PBIAS $=0.31 \%$ were considered to be satisfactory and did not require further efforts in calibrating $\mathrm{HI}$ and WA in the model. RMSE decreased from $3.65 \mathrm{t} \mathrm{ha}^{-1}$ in the default simulation to $1.17 \mathrm{t} \mathrm{ha}^{-1}$ in the PHU calibrated simulation (Table 4).

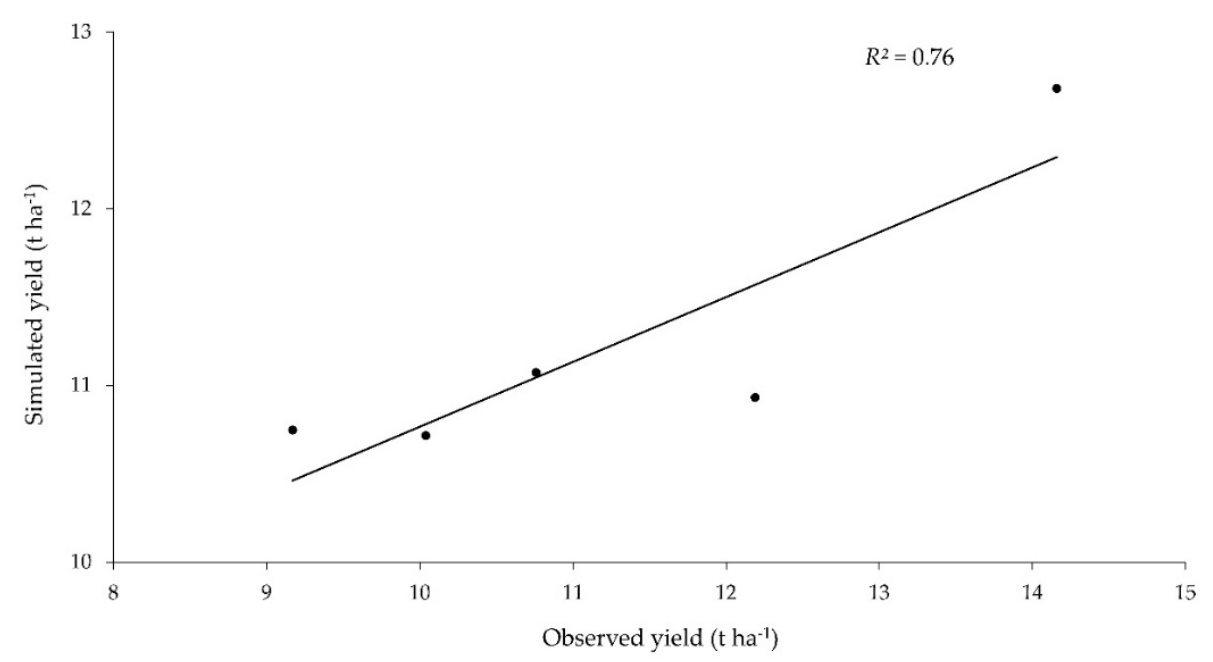

Figure 5. Linear regression of simulated crop yields in tonnes per hectare $\left(\mathrm{t} \mathrm{ha}^{-1}\right)$ on observed maize yields with the calibrated maize crop file.

Table 4. Model evaluation statistics before and after calibration showing Nash-Sutcliffe efficiency (NSE), root-mean-square error percentage (RMSE), and percent bias (PBIAS).

\begin{tabular}{cccccc}
\hline & $\begin{array}{c}\text { Observed } \\
\text { Mean Yield } \\
\left(\mathbf{t ~ h a}^{-\mathbf{1}} \mathbf{)}\right.\end{array}$ & $\begin{array}{c}\text { Simulated } \\
\text { Mean Yield } \\
\mathbf{( t ~ h a}^{-\mathbf{1}} \mathbf{)}\end{array}$ & NSE & $\begin{array}{c}\text { RMSE } \\
\mathbf{( t ~ h a}^{-\mathbf{1}} \mathbf{)}\end{array}$ & PBIAS \\
\hline Before calibration & 11.26 & 8.05 & -3.34 & 3.65 & 28.55 \\
\hline After calibration & 11.26 & 11.23 & 0.56 & 1.17 & 0.31 \\
\hline
\end{tabular}




\subsubsection{Validation}

In the validation site, observed maize yields ranged from $9 \mathrm{t} \mathrm{ha}^{-1}$ to $14 \mathrm{t} \mathrm{ha}^{-1}$ while simulated yields ranged from $10 \mathrm{t} \mathrm{ha}^{-1}$ to $12 \mathrm{t} \mathrm{ha}^{-1}$. The model slightly overestimated maize yields for three out of the five validation years. The year 2000 had exceptionally high observed yields $\left(14.01 \mathrm{tha}^{-1}\right)$, which were under-simulated by the model. The year 2003 had low observed yields, which were overestimated by the model (Figure 6).

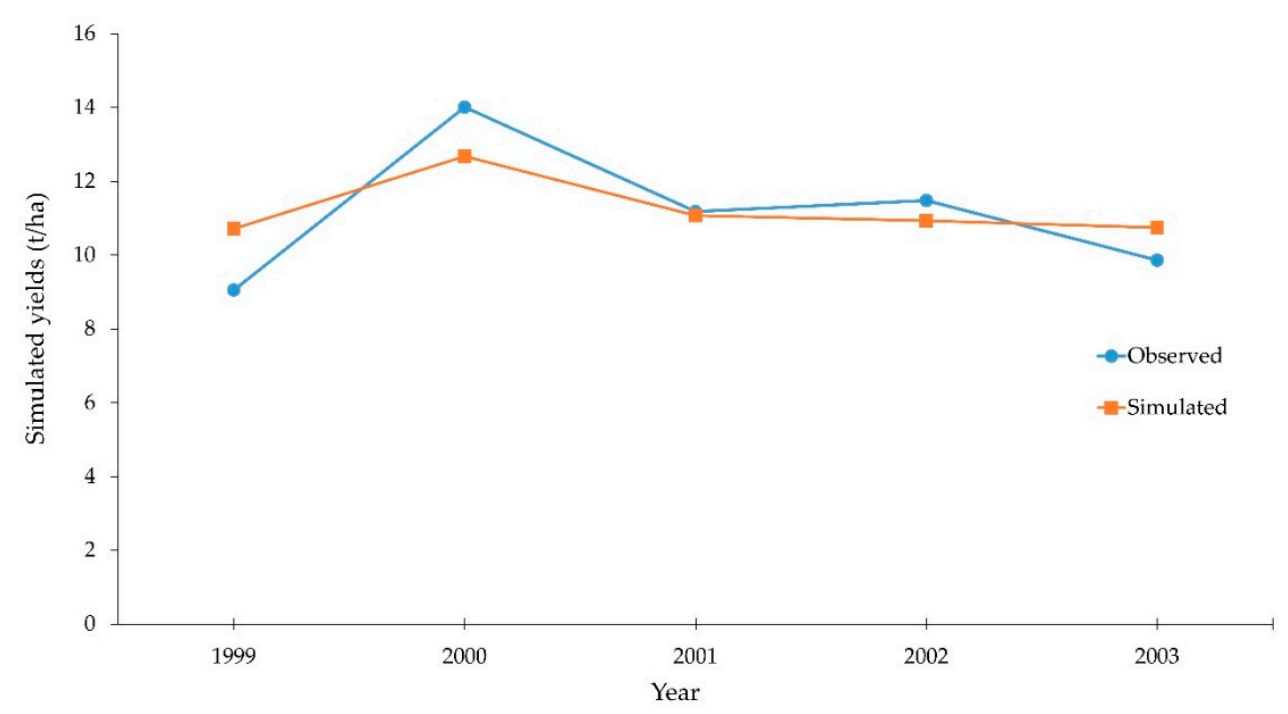

Figure 6. Comparison of observed yields in tonnes per hectare $\left(\mathrm{t} \mathrm{ha}^{-1}\right)$ and simulated yields in the validation simulation with the calibrated model.

The coefficient of determination, $r^{2}$, between observed and simulated yields was 0.85 , as shown in Figure 7. Model performance was satisfactory with NSE $=0.61$, RMSE $=1.06 \mathrm{tha}^{-1}$, and PBIAS $=-1.02$. Table 5 shows a summary of the model statistics for the validation site. A Student's $t$-test comparing the observed and simulated mean grain yields showed that the observed mean yield was not significantly different from the simulated mean yield $(p=0.9)$ at the $95 \%$ significance level.

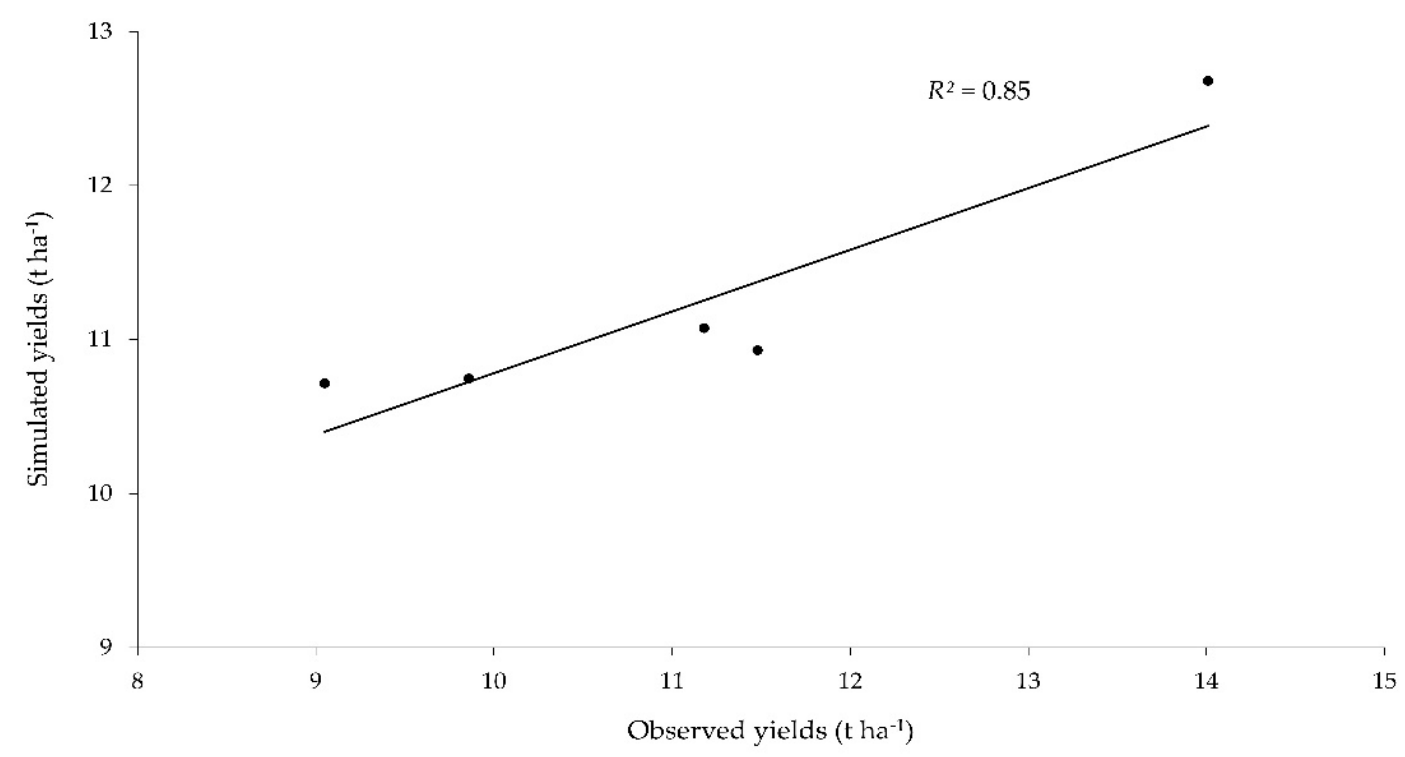

Figure 7. Linear regression of simulated crop yields $\left(\mathrm{t} \mathrm{ha}^{-1}\right)$ on observed maize yields for the validation period. 
Table 5. Mean simulated and observed maize grain yield in tonnes per hectare ( $\left.\mathrm{t} \mathrm{ha}^{-1}\right)$, Nash-Sutcliffe Efficiency (NSE) and root-mean-square error (RMSE) and PBIAS for the validation simulation.

\begin{tabular}{lccccc}
\hline & $\begin{array}{c}\text { Observed } \\
\text { Mean Yield } \\
\left(\mathbf{t ~ h a} \mathbf{~}^{-\mathbf{1}}\right)\end{array}$ & $\begin{array}{c}\text { Simulated } \\
\text { Mean Yield }\left(\mathbf{t} \mathbf{~ h a}^{-\mathbf{1}}\right)\end{array}$ & NSE & $\begin{array}{c}\text { RMSE } \\
\left(\mathbf{t ~ h a}^{-\mathbf{1}}\right)\end{array}$ & PBIAS \\
\hline Validation & 11.12 & 11.23 & 0.61 & 1.06 & -1.02 \\
\hline
\end{tabular}

\section{Discussion}

In this current study, the EPIC crop model was evaluated for its possible use as a decision support tool in irrigation and fertilizer management of crops in a semi-arid condition in South Africa. The success of crop growth simulation models depends on the real-world accuracy of simulating crop yields and other variables of importance. The calibration results of this study displayed a reasonable agreement between observed and simulated crop yields.

Effective parameter estimation is essential in accurately reproducing field conditions. Wang [49] considered that, although the majority models might be effectively used in many environments, uncertainty about many of the parameters persists, and their estimation is important in obtaining useful model results. In this study, the simulation with default parameters gave a poor agreement between observed and simulated yields, indicating the necessity for calibration. However, adjusting parameters related to carbon dynamics using site history and expert knowledge greatly improved model simulations, demonstrating the importance of calibration with site-specific parameters and giving weight to [63] and [12] assertions that detailed data on a local scale can improve the reliability and accuracy of model simulations. Model uncertainty can thus be reduced by using site-specific data.

Adjusting PHU improved crop yield simulations to values nearer to observed yields. This improvement in model simulations is in agreement with studies by [12] and [64], which showed that refinement of PHUs to the specific region could significantly improve the agreement between simulated and observed yields. PHU is directly linked to the growth of biomass and its allocation to final yield, hence the significant effect of PHU adjustment on crop yields. The results of the present study showed that simulated yields were closest to observed yields when PHU was 2480. This value is within the range of PHUs reported in the literature for maize. For example, experiments conducted in the USA by [54], showed that the PHUs required for the maturity of maize vary between 1000 and 2900. The Agricultural Research Council's maize information guide states that maize normally takes 120 days from planting to maturity, but this value is generally for the warmer traditional maize-growing areas in South Africa, such as Kwa-Zulu Natal [65]. The Cradock region is relatively cooler compared to other maize growing areas, which may explain the long duration of the growing season.

By default, the potential HI of maize for the EPIC model is set to 0.5 , which is typical for improved high yield maize varieties [28]. The value of 0.5 was taken as the final calibrated value and is the same as the HI values used by [19] and [66]. The biomass to energy ratio (WA) is a known parameter influencing crop yields [49]. During PHU calibration, a RMSE of $1.17 \mathrm{t} \mathrm{ha}^{-1}$ and PBIAS $=0.31$ between observed and simulated yields were observed, indicating that no further adjustment of WA and HI were needed as acceptable criteria set for model performance had been satisfied. The default value of $40 \mathrm{~kg} \mathrm{ha}^{-1} \mathrm{MJ}^{-1} \mathrm{~m}^{2}$ was therefore adopted as the final calibration value. This value is the same as that used by [67] and [19]. WA increases yield through biomass changes and should be adjusted last based on experimental data as it can significantly change the rate of crop growth and final crop yield [18]. The HI value of 0.5 is also close to values reported in studies in nine states in the USA [66] and the value of 0.48 reported by [49].

Although the model simulated observed yields correctly, in some years the model overestimated low yields. This is in agreement with studies by [68] and [69] that found that EPIC tended to overestimate low yields. Kiniry [55] indicated that overestimation of plant available water at field capacity could cause EPIC to overestimate yields in dry years and suggested measuring the maximum depth of water extraction using local cultivars. However, this was beyond the scope of the present study. In 2003, when 
low maize yields were observed, management records show that the 2003 trials suffered heavy weed infestations. While EPIC successfully simulates water and fertilizer effects on plant growth, currently the model does not accurately account for the competition from weeds [22]. This may explain why the model over-simulated the lower yields observed in 2003. Although EPIC has a pest damage factor, it is only represented as an estimate rather than a detailed process in the model [18].

\section{Conclusions}

The results of the study suggest that limited data from field trials on maize that only include grain yield and agricultural management dates can be used for the calibration of the EPIC model under the semi-arid conditions of South Africa. The evaluation of the EPIC model with observed independent field trial data was reasonably accurate, given the limited data available for model evaluation. However, it is important to calibrate parameters related to carbon dynamics and PHUs according to local conditions as soil and carbon-related parameters, and site-specific PHUs can significantly improve model simulation results. Further studies using the calibrated model that evaluate different crop management options, such as deficit irrigation and fertilizer application timing, should be carried out in the Eastern Cape. Field trials on maize and other crops are also carried out across many sites in South Africa by seed producers to evaluate the stability and potential yield of crop varieties under different weather and soil conditions. Availability of such datasets presents opportunities for the calibration and validation of crop models before their application. Crop model users should make an effort to work with researchers who carry out field trials on crop varieties to ensure collection of detailed data needed for model calibration and validation that are not usually collected by seed producers.

Author Contributions: Conceptualization, D.J.C., J.B., and O.N.O.; model set up J.B and D.J.C.; model simulations, D.J.C.; writing and draft preparation, D.J.C.; writing-review and editing, D.J.C., O.N.O. and J.B.

Funding: This Research was funded by the National Research Foundation, South Africa under the Southern African Systems Analysis Centre (SASAC) initiative.

Acknowledgments: The authors would like to thank Gideon Jordaan and Marina Jordaan of the Cradock Research Farm for their assistance with the experimental field data.

Conflicts of Interest: The authors declare no conflict of interest.

\section{References}

1. Alexandratos, N.; Bruinsma, J. World Agriculture: Towards 2030/2050-The 2012 Revision; FAO: Rome, Italy, 2012.

2. FAO. The Future of Food and Agriculture-Trends and Challenges; FAO: Rome, Italy, 2017.

3. Greer, K.D.; Pittelkow, C.M. Linking Nitrogen Losses with Crop Productivity in Maize Agroecosystems. Front. Sustain. Food Syst. 2018, 2, 29. [CrossRef]

4. Tian, X.; Li, C.; Zhang, M.; Wan, Y.; Xie, Z.; Chen, B.; Li, W. Biochar derived from corn straw affected availability and distribution of soil nutrients and cotton yield. PLoS ONE 2018, 13, e0189924. [CrossRef] [PubMed]

5. Zhou, Z.; Palmborg, C.; Ericson, L.; Dryler, K.; Lindgren, K.; Bergkvist, G.; Parsons, D. A 60-years old field experiment demonstrates the benefit of leys in the crop rotation. Acta Agric. Scand. Sect. B Soil Plant Sci. 2019, 69, 36-42. [CrossRef]

6. Durr, C.; Constantin, J.; Wagner, M.H.; Navier, H.; Demilly, D.; Goertz, S.; Nesi, N. Virtual modeling based on deep phenotyping provides complementary data to field experiments to predict plant emergence in oilseed rape genotypes. Eur. J. Agron. 2016, 79, 90-99. [CrossRef]

7. Liang, H.; Hu, K.; Batchelor, W.D.; Qi, Z.; Li, B. An integrated soil-crop system model for water and nitrogen management in North China. Sci. Rep. 2016, 6, 25755. [CrossRef] [PubMed]

8. Santhi, C.; Srinivasan, R.; Arnold, J.G.; Williams, J.R.; Arnold, J.G. A modeling approach to evaluate the impacts of water quality management plans implemented in a watershed in Texas. Environ. Model. Softw. 2006, 21, 1141-1157. [CrossRef] 
9. Zhao, Z.; Sha, Z.; Liu, Y.; Wu, S.; Zhang, H.; Li, C.; Zhao, Q.; Cao, L.; Zhang, H.; Zhang, H.; et al. Modeling the impacts of alternative fertilization methods on nitrogen loading in rice production in Shanghai. Sci. Total Environ. 2016, 566-567, 1595-1603. [CrossRef]

10. Khan, M.; Walker, D. Application of Crop Growth Simulation Models in Agriculture with Special Reference to Water Management Planning. Int. J. Core Eng. Manag. 2015, 2, 113-130.

11. Folberth, C.; Gaiser, T.; Abbaspour, K.C.; Schulin, R.; Yang, H. Regionalization of a large-scale crop growth model for sub-Saharan Africa: Model setup, evaluation, and estimation of maize yields. Agric. Ecosyst. Environ. 2012, 151, 21-33. [CrossRef]

12. Xiong, W.; Balkovič, J.; Van Der Velde, M.; Zhang, X.; Izaurralde, R.C.; Skals, R.; Lin, E.; Mueller, N.; Obersteiner, M. A calibration procedure to improve global rice yield simulations with EPIC. Ecol. Model. 2013, 273, 128-139. [CrossRef]

13. Daggupati, P.; Pai, N.; Ale, S.; Douglas-Mankin, K.R.; Zeckoski, R.W.; Jeong, J.; Parajuli, P.B.; Saraswat, D.; Youssef, M.A. A Recommended Calibration and Validation Strategy for Hydrologic and Water Quality Models. Trans. ASABE 2015, 58, 1705-1719.

14. Arnold, J.G.; Moriasi, D.N.; Gassman, P.W.; Abbaspour, K.C.; White, M.J.; Srinivasan, R.; Santhi, C.; Harmel, R.D.; Van Griensven, A.; Van Liew, M.W.; et al. SWAT: Model Use, Calibration and Vaidation. Trans. $A S A B E$ 2012, 55, 1491-1508. [CrossRef]

15. James, L.; Burges, S.J. Selection, Calibration, and Testing of Hydrologic Models. In Hydrologic Modeling of Small Watersheds; Haan, C., Johnson, H., Brakensiek, D., Eds.; ASAE Monograph: St. Joseph, MO, USA, 1982.

16. Moriasi, D.N.; Arnold, J.G.; Van Liew, M.W.; Bingner, R.L.; Harmel, R.D.; Veith, T.L. Model Evaluation Guidelines for Systematic Quantification of Accuracy in Watershed Simulations. Trans. ASABE 2007, 50, 885-900. [CrossRef]

17. Williams, J.R.; Jones, C.A.; Dyke, P.T. A modeling approach to determining the relationship between erosion and soil productivity. Trans. ASAE 1984, 27, 129-144. [CrossRef]

18. Williams, J.; Gerik, T.; Dagitz, S.; Magre, M.; Meinardus, A.; Steglich, E.; Taylor, R. Environmental Policy Integrated Climate Model-Users Manual Version 0810 2015; Blackland Research and Extension Center: Temple, TX, USA, 2015.

19. Balkovič, J.; Van Der Velde, M.; Schmid, E.; Skalsk, R.; Obersteiner, M.; Stürmer, B.; Xiong, W. Pan-European crop modelling with EPIC: Implementation, up-scaling and regional crop yield validation. Agric. Syst. 2013, 120, 61-75. [CrossRef]

20. Folberth, C.; Yang, H.; Gaiser, T.; Abbaspour, K.C.; Schulin, R. Modeling maize yield responses to improvement in nutrient, water and cultivar inputs in sub-Saharan Africa. Agric. Syst. 2013, 119, 22-34. [CrossRef]

21. Zhang, J.; Balkovič, J.; Azevedo, L.B.; Skalský, R.; Bouwman, A.F.; Xu, G.; Wang, J.; Xu, M.; Yu, C. Analyzing and modelling the effect of long-term fertilizer management on crop yield and soil organic carbon in China. Sci. Total Environ. 2018, 627, 361-372. [CrossRef]

22. Ko, J.; Piccinni, G.; Steglich, E. Using EPIC model to manage irrigated cotton and maize. Agric. Water Manag. 2009, 96, 1323-1331. [CrossRef]

23. Rinaldi, M. Application of EPIC model for irrigation scheduling of sunflower in Southern Italy. Agric. Water Manag. 2001, 49, 185-196. [CrossRef]

24. Van Zelm, R.; van der Velde, M.; Balkovic, J.; Čengić, M.; Elshout, P.M.F.; Koellner, T.; Núñez, M.; Obersteiner, M.; Schmid, E.; Huijbregts, M.A.J. Spatially explicit life cycle impact assessment for soil erosion from global crop production. Ecosyst. Serv. 2018, 30, 220-227. [CrossRef]

25. Lychuk, T.E.; Hill, R.L.; Izaurralde, R.C.; Momen, B.; Thomson, A.M. Evaluation of climate change impacts and effectiveness of adaptation options on crop yield in the Southeastern United States. Field Crops Res. 2017, 214, 228-238. [CrossRef]

26. Xiong, W.; Skalský, R.; Porter, C.H.; Balkovič, J.; Jones, J.W.; Yang, D. Calibration-induced uncertainty of the EPIC model to estimate climate change impact on global maize yield. J. Adv. Model. Earth Syst. 2016, 8, 1358-1375. [CrossRef]

27. Adejuwon, J.O. Assessing the Suitability of the EPIC Crop Model for Use in the Study of Impacts of Climate Variability and Climate Change in West Africa. Singap. J. Trop. Geogr. 2005, 26, 44-60. [CrossRef]

28. Gaiser, T.; de Barros, I.; Sereke, F.; Lange, F.M. Validation and reliability of the EPIC model to simulate maize production in small-holder farming systems in tropical sub-humid West Africa and semi-arid Brazil. Agric. Ecosyst. Environ. 2010, 135, 318-327. [CrossRef] 
29. Worou, O.N.; Gaiser, T.; Saito, K.; Goldbach, H.; Ewert, F. Simulation of soil water dynamics and rice crop growth as affected by bunding and fertilizer application in inland valley systems of West Africa. Agric. Ecosyst. Environ. 2012, 162, 24-35. [CrossRef]

30. Van der Velde, M.; Folberth, C.; Balkovič, J.; Ciais, P.; Fritz, S.; Janssens, I.A.; Obersteiner, M.; See, L.; Skalský, R.; Xiong, W.; et al. African crop yield reductions due to increasingly unbalanced Nitrogen and Phosphorus consumption. Glob. Chang. Biol. 2014, 20, 1278-1288. [CrossRef] [PubMed]

31. Singels, A.; Annandale, J.G.; De Jager, J.M.; Schulze, R.E.; Inman-Bamber, N.G.; Durand, W.; Van Rensburg, L.D.; Van Heerden, P.S.; Crosby, C.T.; Green, G.C.; et al. Modelling crop growth and crop water relations in South Africa: Past achievements and lessons for the future. S. Afr. J. Plant Soil 2010, 27, 49-65. [CrossRef]

32. Zinyengere, N.; Crespo, O.; Hachigonta, S.; Tadross, M. Crop model usefulness in drylands of southern Africa: An application of DSSAT. S. Afr. J. Plant Soil 2015, 32, 95-104. [CrossRef]

33. Arunrat, N.; Pumijumnong, N.; Hatano, R. Predicting local-scale impact of climate change on rice yield and soil organic carbon sequestration: A case study in Roi Et Province, Northeast Thailand. Agric. Syst. 2018, 164, 58-70. [CrossRef]

34. Therond, O.; Hengsdijk, H.; Casellas, E.; Wallach, D.; Adam, M.; Belhouchette, H.; Oomen, R.; Russell, G.; Ewert, F.; Bergez, J.E.; et al. Using a cropping system model at regional scale: Low-data approaches for crop management information and model calibration. Agric. Ecosyst. Environ. 2011, 142, 85-94. [CrossRef]

35. Kollongei, K.J.; Lorentz, S.A. Modelling hydrological processes, crop yields and NPS pollution in a small sub-tropical catchment in South Africa using ACRU-NPS. Hydrol. Sci. J. 2015, 60, 2003-2028. [CrossRef]

36. Schulze, R.; Arnold, H. Hydrological Models for Application to Small Rural Catchments in Southern Africa: Refinements and Development; Water Research Commission: Pretoria, South Africa, 1984.

37. Jones, J.; Hoogenboom, G.; Porter, C.; Boote, K.; Batchelor, W.; Hunt, L.; Wilkens, P.; Singh, U.; Gijsman, A.; Ritchie, J. The DSSAT cropping system model. Eur. J. Agron. 2003, 18, 235-265. [CrossRef]

38. Annandale, J.G.; Steyn, J.M.; Benadé, N.; Jovanovic, N.Z.; Soundy, P. Technology Transfer of the Soil Water Balance (SWB) Model as a User Friendly Irrigation Scheduling Tool; Water Research Commission: Pretoria, South Africa, 2005.

39. Soil Survey Staff. Keys to Soil Taxonomy, 12th ed.; USDA, NRCS, Eds.; USDA: Washington, DC, USA, 2014.

40. Goldblatt, A. Agriculture: Facts and Trends South Africa; World Wide Fund Nature-South Africa: South Africa, 2011; pp. 2-26.

41. Clewer, A.G.; Scarisbrick, D.H. Practical Statistics and Experimental Design for Plant and Crop Science; Wiley: Hoboken, NJ, USA, 2001; ISBN 9780471899082.

42. Ruane, A.C.; Goldberg, R.; Chryssanthacopoulos, J. Climate forcing datasets for agricultural modeling: Merged products for gap-filling and historical climate series estimation. Agric. For. Meteorol. 2015, 200, 233-248. [CrossRef]

43. FAO; IIASA; ISRIC; ISS-CAS; JRC. Harmonized World Soil Database; Version 1.1; FAO: Rome, Italy; IIASA: Laxenburg, Austria, 2009.

44. Jordaan, G.; Cradock Research Farm, Cradock, South Africa. Personal Communication, 2017.

45. ARC. Maize Information Guide; Shereno Printers: Boksburg, South Africa, 2017.

46. Bondesio, S.; Kloppers, R.; Oellermann, H. Know the Maize Plant; Pannar Quality Seeds: South Africa, 2018.

47. Balkovič, J.; van der Velde, M.; Skalský, R.; Xiong, W.; Folberth, C.; Khabarov, N.; Smirnov, A.; Mueller, N.D.; Obersteiner, M. Global wheat production potentials and management flexibility under the representative concentration pathways. Glob. Planet. Chang. 2014, 122, 107-121. [CrossRef]

48. Schulze, R.; Maharaj, M. A-Pan Equivalent Reference Potential Evaporation; Schulze, R.E., Ed.; School of Bioresources Engineering and Environmental Hydrology, University of KwaZulu-Natal: Pietermaritzburg, South Africa, 2007.

49. Wang, X.; He, X.; Williams, J.R.; Izaurralde, R.; Atwood, J.D. Sensitivity an Uncertainity Analysis of Crop Yields and Soil Organic Carbon Simulated with EPIC. Trans. ASAE 2005, 48, 1041. [CrossRef]

50. Causarano, H.J.; Doraiswamy, P.C.; Muratova, N.; Pachikin, K.; Mccarty, G.W.; Akhmedov, B.; Williams, J.R. Improved modeling of soil organic carbon in a semiarid region of Central East Kazakhstan using EPIC. Agron. Sustain. Dev. 2010, 31, 275-286. [CrossRef]

51. Rinaldi, M.; Garofalo, P.; Rubino, P.; Steduto, P. Processing tomatoes under different irrigation regimes in Southern Italy: Agronomic and economic assessments in a simulation case study. Ital. J. Agrometeorol. 2011, 3, 39-56. 
52. Balkovic, J.; International Institute of Applied Systems Analysis, Laxenburg, Austria. Personal Communication, 2018.

53. Folberth, C.; Elliott, J.; Müller, C.; Balkovic, J.; Chryssanthacopoulos, J.; Izaurralde, R.C.; Jones, C.D.; Khabarov, N.; Liu, W.; Reddy, A.; et al. Uncertainties in global crop model frameworks: Effects of cultivar distribution, crop management and soil handling on crop yield estimates. Biogeosci. Discuss. 2016, 1-30. [CrossRef]

54. Williams, J.R.; Jones, C.A.; Kiniry, J.R.; Spanel, D.A. The EPIC Crop Growth Model. Trans. ASAE 1989, 32, 497-511. [CrossRef]

55. Kiniry, J.R.; Major, D.; Izaurralde, R.; Williams, J.; Gassmann, P.; Morrison, M.; Bergentine, R.; Zentner, R. EPIC model parameters for cereal, oilseed, and forage crops in the northern Great Plains region. Can. J. Plant Sci. 1995, 75, 679-688. [CrossRef]

56. Sinclair, T.; Muchow, R. Radiation Use Efficiency. Adv. Agron. 1999, 65, 215-265.

57. Causarano, H.J.; Shaw, J.N.; Franzluebbers, A.J.; Reeves, D.W.; Raper, R.L.; Balkcom, K.S.; Norfleet, M.L.; Izaurralde, R.C. Simulating Field-Scale Soil Organic Carbon Dynamics Using EPIC. Soil Sci. Soc. Am. J. 2007, 71, 1174. [CrossRef]

58. Steglich, E.; Jeong, J.; Williams, J.; Zhang, J. Agricultural Policy/Environmental Extender Model: User's Manual Version 1501; Blackland Research and Extension Center: Temple, TX, USA, 2016.

59. Worou, O.N.; Gaiser, T.; Oikeh, S. Sensitive parameters for EPIC model evaluation and validity under soil water and nutrients limited conditions with NERICA cropping in West Africa. Afr. J. Agric. Res. 2015, 10, 2286-2299.

60. Bao, Y.; Hoogenboom, G.; McClendon, R.; Vellidid, G. A comparison of the performance of the CSM-CERES-Maize and EPIC models using maize variety trial data. Agric. Syst. 2017, 150, 109-119. [CrossRef]

61. Gupta, H.V.; Sorooshian, S.; Yapo, P.O. Status of Automatic Calibration for Hydrologic Models: Comparison with Multilevel Expert Calibration. J. Hydrol. Eng. 1999, 4, 135-143. [CrossRef]

62. Wang, X.; Williams, J.R.; Gassman, P.W.; Baffaut, C.; Izaurralde, R.C.; Jeong, J.; Kiniry, J.R. EPIC and APEX: Model Use, Calibration, and Validation. Trans. ASABE 2012, 55, 1447-1462. [CrossRef]

63. Niu, X.; Easterling, W.; Hays, C.J.; Jacobs, A.; Mearns, L. Reliability and input-data induced uncertainty of the EPIC model to estimate climate change impact on sorghum yields in the U.S. Great Plains. Agric. Ecosyst. Environ. 2009, 129, 268-276. [CrossRef]

64. Angulo, C.; Rötter, R.; Lock, R.; Enders, A.; Fronzek, S.; Ewert, F. Implication of crop model calibration strategies for assessing regional impacts of climate change in Europe. Agric. For. Meteorol. 2013, 170, $32-46$. [CrossRef]

65. Du Plessis, J. Maize Production; Department of Agriculture: Pretoria, South Africa, 2003.

66. Kiniry, J.R.; Williams, J.R.; Vanderlip, R.L.; Atwood, J.D.; Reicosky, D.C.; Mulliken, J.; Cox, W.J.; Mascagni, H.J.; Hollinger, S.E.; Wiebold, W.J. Evaluation of Two Maize Models for Nine U.S. Locations. Agron. J. 1997, 89, 421. [CrossRef]

67. Wang, X.; Li, J.; Naveed Tahir, M.; De Hao, M. Validation of the EPIC model using a long-term experimental data on the semi-arid Loess Plateau of China. Math. Comput. Model. 2011, 54, 976-986. [CrossRef]

68. Martin, S. An evaluation of the EPIC model for soybeans grown in Southern Piedmont soils. Trans. ASABE 1993, 36, 1327-1331. [CrossRef]

69. Warner, G.; Stake, J.; Guillard, K. Evaluation of EPIC for a shallow New England soil: I. Maize yield and nitrogen uptake. Trans. ASABE 1997, 40,575-583. [CrossRef]

(C) 2019 by the authors. Licensee MDPI, Basel, Switzerland. This article is an open access article distributed under the terms and conditions of the Creative Commons Attribution (CC BY) license (http://creativecommons.org/licenses/by/4.0/). 